\title{
BM] Global Health Reforming the regulation of medical education, professionals and practice in India
}

\author{
Vikash Ranjan Keshri (D) , ${ }^{1,2}$ Veena Sriram (D) , ${ }^{3}$ Rama Baru ${ }^{4}$
}

To cite: Keshri VR, Sriram V, Baru R. Reforming the regulation of medical education, professionals and practice in India. BMJ Global Health 2020;5:e002765. doi:10.1136/ bmjgh-2020-002765

Handling editor Seye Abimbola

Received 27 April 2020

Revised 13 July 2020

Accepted 28 July 2020

\section{Check for updates}

C) Author(s) (or their employer(s)) 2020. Re-use permitted under CC BY-NC. No commercial re-use. See rights and permissions. Published by BMJ.

${ }^{1}$ Injury Division, The George Institute for Global Health India, New Delhi, India

${ }^{2}$ Faculty of Medicine, University of New South Wales, Sydney, New South Wales, Australia

${ }^{3}$ Center for Health and the Socia Sciences, University of Chicago, Chicago, Illinois, USA

${ }^{4}$ Centre of Social Medicine and Community Health, Jawaharlal Nehru University, New Delhi, India

Correspondence to Dr Vikash Ranjan Keshri; VKeshri@georgeinstitute.org.in

\section{INTRODUCTION}

The regulation of medical education and health professionals is an important aspect of the governance of health systems. This has been an area of concern and institutional weakness in many low and middle-income countries (LMICs) including India. ${ }^{12}$ In 2019, the Indian government addressed the longstanding demand to reform medical education by dismantling the Medical Council of India (MCI), a regulatory body formed during the preindependence era, and established a new institution, the National Medical Commission (NMC). ${ }^{3}$ The NMC comes at a crucial phase for the Indian health sector, where reforms over the last few decades have taken an unmistakable turn towards privatisation. ${ }^{4}$ Like several other LMICs with an underfunded public sector and poorly regulated private sector, the expanding role of commercial actors in healthcare and medical education in India has posed major regulatory challenges. Compounding these issues are a growing lack of trust between doctors and patients and diminishing autonomy for doctors in the face of corporate demands. ${ }^{56}$

It is well recognised that the health workforce is key for achieving universal health coverage (UHC), but few analyses have focused on the coherence between education and training policies for the health workforce and UHC. ${ }^{7}$ Recent experiences in India are illustrative in unpacking these thorny dynamics between financing and service delivery reforms, health workforce production and regulation. What does the establishment of NMC in India during this conflicting trend of increased corporatisation and a professed commitment to UHC imply for overall health systems? In this commentary, we situate the reform being envisaged through NMC in this wider health policy and systems context in India. After providing contextual background, we focus our arguments around three themes-medicalisation, corporatisation and centralisation. We conclude our piece by discussing the implications of these trends on public health and health systems in India.

\section{CONTEXT}

For many decades, the former MCI was accused of corruption and mismanagement, but also proved to be resistant to reform. ${ }^{8}$ The formal process of formulating the NMC began in 2016 but faced severe resistance from many quarters, including medical students, medical colleges and professional associations. ${ }^{9}{ }^{10}$ In the meantime, when the NMC Bill was pending in Parliament, the existing MCI was superseded by a government-appointed Board of Governors (BoG) in 2018. ${ }^{11}$ The NMC Act was ultimately approved by the Parliament in 2019 (table 1).

The responsibilities of NMC not only include those of the existing MCI but go beyond to include the realm of fee structures for private colleges and common exit examinations, as well as more rigorously regulating ethical practice. The NMC has also veered into an unknown and contentious territory, by including in its mandate the training and licensure of a new cadre of non-physician clinicians, called community health providers (CHP) (table 2). The NMC is mandated to be functional from the time the central government issues a notification. Currently, while some members of the NMC have been nominated and the chairperson is appointed, the institution is yet to be functional. ${ }^{3}{ }^{12} \mathrm{In}$ the meantime, the interim BoG continues to make decisions in the realm of medical education. $^{11}$

The past decade has also been highly formative for the overall Indian health sector, resulting in expanded financial protection schemes for the poor while also promoting 


\begin{tabular}{|c|c|}
\hline Year & Major development \\
\hline 1933 & Indian Medical Council Act, 1933 (preindependence)* \\
\hline 1934 & Establishment of Medical Council of India $(\mathrm{MCl})^{\star}$ \\
\hline 1956 & The Indian Medical Council Act, 1956 (postindependence)* \\
\hline 1982 & $\begin{array}{l}\text { Medical Education and Review Committee (Mehta Committee) } \dagger \\
\text { Recommended reform in medical education, such as entrance examination for admission to undergraduate } \\
\text { (UG) and postgraduate (PG) medical courses, revising the curriculum of UG and PG, and setting up } \\
\text { institutional norms for standardising medical education. }\end{array}$ \\
\hline 1986 & $\begin{array}{l}\text { Expert Committee for Health Manpower Planning, Production and Management (Bajaj Committee) } \neq \\
\text { Recommended formulation of national medical and health education policy, cadre-wise coordinated planning } \\
\text { and setting of university of health sciences within states in India. } \\
\text { Estimated availability of human resources for health. }\end{array}$ \\
\hline 2007 & $\begin{array}{l}\text { Planning commission task force on human resources in health§ } \\
\text { Provided report on assessment and future requirement. }\end{array}$ \\
\hline 2008 & $\begin{array}{l}\text { National Knowledge Commission-subcommittee on medical education } 1 \\
\text { Recommended converting the } \mathrm{MCl} \text { into a full-fledged professional body conducting examination and licensing } \\
\text { of medical professionals only. }\end{array}$ \\
\hline 2011 & $\begin{array}{l}\text { The National Commission for Human Resources for Health Bill, } 2011 \text { (withdrawn) }{ }^{\star \star} \\
\text { Recommended reform in regulation of health professional education by dissolving the } \mathrm{MCl} \text {, the Nursing } \\
\text { Council, the Pharmacy Council and the Dental Council and replacing them with one comprehensive regulatory } \\
\text { institution. }\end{array}$ \\
\hline 2011 & $\begin{array}{l}\text { High Level Expert Group on Universal Health Coverage } \dagger \\
\text { Recommended establishing more medical institution in public sector in underserved area, reserving } 50 \% \text { seats } \\
\text { for local communities in private institutions. } \\
\text { Sector medical institutes, fixed fee and revision of medical curriculum. }\end{array}$ \\
\hline 2015 & $\begin{array}{l}\text { Expert Committee led by Dr Ranjit Roy Chaudhury } \neq \ddagger \\
\text { Recommended overhaul of } \mathrm{MCl} \text { and replace it with new institution. }\end{array}$ \\
\hline 2017 & $\begin{array}{l}\text { The National Medical Commission Bill, } 2017 \S \S \\
\text { Proposed to replace the existing } \mathrm{MCl} \text { with a new body, the National Medical Commission (NMC). It } \\
\text { encountered severe resistance from professional associations and medical students. Not approved by the } \\
\text { Parliament and referred to parliamentary standing committee. }\end{array}$ \\
\hline 2017 & $\begin{array}{l}\text { The National Health Policy, } 2017 \uparrow \uparrow \\
\text { Recommended recreating the regulatory mechanism for health professional education. }\end{array}$ \\
\hline 2018 & $\begin{array}{l}\text { The Indian Medical Council (Amendment) Ordinance, } 2018^{\star \star \star} \\
\text { Notified superseding of the } \mathrm{MCl} \text { and replacing it by an interim Board of Governors. }\end{array}$ \\
\hline 2019 & $\begin{array}{l}\text { The National Medical Commission Act, } 2019+\uparrow \dagger \\
\text { Approved by the Indian Parliament thus clearing the roadblock for constitution of new regulatory body for } \\
\text { medical education, the NMC. }\end{array}$ \\
\hline
\end{tabular}

\footnotetext{
${ }^{*}$ The medical council of India

†Ministry of Health and Family Welfare, Government of India- Report of the medical education review committee, 1983

$\ddagger$ National Health Portal, India - Report of expert committee for health manpower planning, production and management,1985

§Planning Commission, Government of India -Task force on planning for human resource in health sector, 2007

INational Knowledge Commission, Government of India - Recommendations on medical education, 2008

**PRS legislative Research- The National Commission for Human Resources for Health Bill, 2011

$\dagger †$ National Health Mission - Full report on highlevel expert group on universal health coverage, 2011

$\ddagger \ddagger$ NITI Aayog, Government of India - A Preliminary Report of the Committee on the Reform of the IndianMedical Council Act, 1956

$\S \S P R S$ Legislative Research. The National MedicalCommission Bill, 2017

ๆqGovernment of India. National Health Policy, 2017

${ }^{* *}$ Government of India. The Indian Medical Commission(Amendment) Ordinance, 2018

†††Government of India. The National Medical CommissionAct

$\mathrm{MCl}$, Medical Council of India; NMC, National Medical Commision; PG, Postgraduate; UG, Undergraduate.
}

privatisation. The most recent National Health Policy in 2017 emphasises the need to align the private sector with public health goals and suggests strategic purchasing from the private sector. ${ }^{13}$ Many recent government health policy initiatives have included measures that strengthen commercialisation, for example, having 'viability gap funding' for private hospitals, and setting up private medical colleges in partnership with public 
Table 2 Medical Council of India and National Medical Commission: major differences in governance and responsibilities

\begin{tabular}{|c|c|}
\hline Medical Council of India (MCl)* & National Medical Commission (NMC)† \\
\hline $\begin{array}{l}\text { GOVERNANCE } \\
\text { Composition } \\
\text { Council of members headed by president } \\
\text { President and vice-president elected by the council of members } \\
\text { Most of the members from medical fraternity } \\
\text { Representation from each state, each state medical council and } \\
\text { medical faculties of all universities } \\
\text { Eight members nominated by the central government directly } \\
\text { Seven members elected by medical doctors } \\
\text { Organisation } \\
\text { Executive committee headed by president with } 7-10 \text { members } \\
\text { elected by council members } \\
\text { Subcommittees of undergraduate committee, postgraduate } \\
\text { committee and other committee constituted from time to time }\end{array}$ & $\begin{array}{l}\text { GOVERNANCE } \\
\text { Composition } \\
\text { Commission headed by chairperson appointed by the central } \\
\text { government from among medical person of eminence } \\
10 \text { ex officio members including head of four subcommittees of } \\
\text { NMC and others nominated by central government } \\
22 \text { part-time members - } 10 \text { members from among nominees } \\
\text { of state governments, } 19 \text { members from states and } 3 \text { from other } \\
\text { relevant fields such as law and ethics } \\
\text { Secretary of Central Ministry of Health to be convenor-member } \\
\text { Organisation } \\
\text { The National Medical Commission } \\
\text { The Medical Advisory Council-headed by the chairperson of NMC } \\
\text { and includes members nominated by the state governments and } \\
\text { universities } \\
\text { Autonomous boards - appointed by central government and } \\
\text { function under the aegis of NMC. These are: } \\
\text { The undergraduate medical education board } \\
\text { The postgraduate medical education board } \\
\text { The medical assessment and rating board } \\
\text { The ethics and medical registration board }\end{array}$ \\
\hline $\begin{array}{l}\text { RESPONSIBILITIES } \\
\text { Recognition of medical qualification } \\
\text { Curriculum design and regulation } \\
\text { Standard of examination for awarding medical degrees } \\
\text { Recognition of medical colleges and medical courses by } \\
\text { ensuring minimum standard } \\
\text { Licensing of qualified medical professionals and maintaining } \\
\text { registry } \\
\text { Disqualification of medical professional in case of professional } \\
\text { misconduct } \\
\text { - Protecting the rights of registered medical professionals }\end{array}$ & $\begin{array}{l}\text { RESPONSIBILITIES } \\
\text { Examination-common national entrance and exit examination test } \\
\text { for UG and PG medical courses } \\
\text { Setting and maintaining the standard of medical education } \\
\text { Rating of medical institutions based on defined minimum standards } \\
\text { Maintain national registry of medical professionals } \\
\text { Regulate professional conduct and promote medical ethics } \\
\text { Recognition of medical colleges and medical courses by ensuring } \\
\text { minimum standard } \\
\text { Licensing of a cadre of community health provider (CHP) } \\
\text { Ensuring rights and obligations of registered medical professionals } \\
\text { Recognition of postgraduate medical degree awarded by the } \\
\text { Diplomate of National Board }\end{array}$ \\
\hline
\end{tabular}

*The Indian Medical Council Act, 1956

†The National Medical Commission Act, 2019

CHP, Community Health Provider; MCl, Medical Council of India; NMC, National Medical Commission; PG, postgraduate; UG, undergraduate.

district hospitals. ${ }^{14}$ The most significant reform in recent times is 'Ayushman Bharat' (Long live India) which started in 2018 and includes a publicly financed health insurance scheme for the poor for availing secondary and tertiary care services, and health and wellness centres for provision of primary care. ${ }^{15}$ What is less clear is how these reforms in the health sector and in medical education cohere. We posit that rather than emphasising an approach driven by primary care, health equity and social justice, the current policies together promote medicalisation and corporatisation of healthcare. Additionally, rather than constituting an accountable, inclusive and transparent governance structure, current policies could result in centralisation of authority that excludes key constituents.

\section{MEDICALISATION}

It is evident that recent reforms in healthcare delivery have shifted the focus to providing curative medical care, at the expense of preventive and promotive care. ${ }^{16} \mathrm{~A}$ key constraint facing both the public and private sectors in such a medicalised model is the availability of doctors. ${ }^{17}$ Therefore, it is even more intriguing to note that after superseding the MCI in 2018, the intermediate BoG started a series of reform in medical education, targeted at increasing intake of undergraduate medical students and more importantly, students training for postgraduate studies in medical specialties. ${ }^{18}$ Interestingly, the NMC Act explicitly calls for an expansion in Family Medicine postgraduate programmes, a development that could support efforts to expand primary care; however, it is unclear how stakeholders plan to proceed on this front. ${ }^{3}$

Broadly, the reforms put forward by the NMC comprised relaxing the existing norms, thus resulting in significant increase in the student intake and eventually the number of general and specialist doctors. However, as the number of government medical colleges was insufficient to undertake the desired increase, the focus in privatisation has raised several questions around equity and quality. ${ }^{19}$ The rush for expansion of private medical colleges will also restrict access to those who can pay for higher education or will put significant financial burden on other families. Evidence also shows that the quality of medical education, particularly in the private sector, is variable, so there are questions around the skill and competencies of the physicians so trained..$^{20}$ 


\section{CORPORATISATION}

The process of privatisation of medical education in India started in the early 1980s and the first ever health policy in India, the National Health Policy 1983, also promoted private sector for curative care, which also incidentally proved incredibly challenging to regulate effectively. ${ }^{21}$ When the production of medical professionals increased, resource-constrained public systems struggled to provide employment opportunities to medical graduates, particularly specialists. ${ }^{6}$ In the current privatised and increasingly corporatised health system in India, medical professionals are heavily incentivised to work for the private corporate sector, a sector which has thus far not actively supported primary care, particularly for the poor. This may result in even bigger challenges around reprofessionalisation of medicine and medical professionals. ${ }^{6}$ Recent decisions by the BoG have allowed profit-making companies and even consortium of companies to start medical colleges, suggesting an emerging corporatisation of medical education too along with overall healthcare system. ${ }^{22}$ Moreover, India is the only country where two parallel systems for medical specialisation are running. ${ }^{2}$ The National Board of Examinations (NBE) is a separate body which runs specialty and superspecialty trainings, including in non-academic corporate hospitals. Earlier drafts included the NBE within the NMC, but the Act is now silent on the incorporation of NBE courses.

\section{CENTRALISATION}

These trends of medicalisation and corporatisation are enabled and reinforced by the centralisation of governance of regulatory institutions, seemingly excluding voices that could bolster calls for primary care. The composition of NMC is overwhelmingly dependent on selection and nominations by the central government. Such governance structure implicitly puts the central government in the driving seat (table 2). Similarly, the interim BoG is headed by a member of a central government think tank and almost all other members are from central government institutions. ${ }^{23}$ It is interesting to note how centralisation is pushed in order to expedite the reforms in medical education to support medicalised and corporatised model of UHC. Governance structures that involve practitioners working in rural areas and in primary care would be important in developing holistic, equity-driven reforms.

\section{IMPLICATIONS FOR PUBLIC HEALTH AND HEALTH SYSTEMS}

The focus of NMC reforms is ostensibly to reform the medical education sector. Nevertheless, how NMC addresses its responsibilities has significant implications for public health and health systems in India. First, the paradigm shift in approach to UHC with a privatised model may further aggravate the scarcity of human resources for health (HRH) in the public sector health systems. Second, the current inequity in distribution of HRH may worsen if policies continue to prioritise secondary and tertiary care, which are often located in periurban or urban centres. Third, the concept of CHP as envisioned in recent health policy is innovative but if not implemented in the right spirit and manner may further fragment the already fragmented primary healthcare systems.

The NMC is envisaged to be a major reform but it remains to be seen how the institution will address the inefficiencies and issues of corruption which was associated with the erstwhile MCI. The inefficiencies, variable quality of education and corruption, especially in the private sector will require more effective and robust regulation, free of all conflict of interests. The well-intentioned policy of regulating the fee by private medical institutions will also require test of time, especially with more privatisation, corporatisation and centralisation. The NMC Act is also silent on how the influence of private corporate sector, including pharmaceutical industries, will affect medical education and healthcare services. More importantly, how will the NMC deal with two opposite paradigms of facilitating production of more doctors and specialists, and CHPs? Remarkably, the NMC has also provisioned a specialised medical ethics and regulation board but the real challenge will be to regulate the relationship between the industries, such as the pharmaceutical industry, and medical practitioners, and its influence on ethical practice.

\section{CONCLUSION}

Reforms to improve the regulation of health professionals must work in concert with other reforms pertaining to UHC. As evidenced by the current scenario in India, the vision for the health workforce currently promoted through regulatory reform raises a host of questions, and, importantly, suggests that the mutually reinforcing trends of medicalisation, corporatisation and centralisation could hamper meaningful progress towards UHC. Clear articulations of a health workforce vision, supported by strong regulatory policies and institutions, centred around primary healthcare, are urgently required in India if we are to achieve our goals of access, quality and equity.

Twitter Vikash Ranjan Keshri @docVRK

Acknowledgements The authors acknowledge the comments of Dr Seye Abimbola in the draft version of this paper. The authors also acknowledge the comments of two anonymous reviewers which helped in revising the paper.

Contributors VS conceived the idea in discussion with VRK and RB. VRK, VS and RB decided the outline and central arguments. VRK drafted the first version of the manuscript with inputs from VS and RB. VRK, VS and RB reviewed the draft to develop and finalise the concepts in the final manuscript. Finally, all the authors reviewed and approved the final manuscript.

Funding The authors have not declared a specific grant for this research from any funding agency in the public, commercial or not-for-profit sectors.

Competing interests None declared.

Patient consent for publication Not required.

Provenance and peer review Not commissioned; externally peer reviewed. 
Data availability statement There are no data in this work.

Open access This is an open access article distributed in accordance with the Creative Commons Attribution Non Commercial (CC BY-NC 4.0) license, which permits others to distribute, remix, adapt, build upon this work non-commercially, and license their derivative works on different terms, provided the original work is properly cited, appropriate credit is given, any changes made indicated, and the use is non-commercial. See: http://creativecommons.org/licenses/by-nc/4.0/.

\section{ORCID iDs}

Vikash Ranjan Keshri http://orcid.org/0000-0001-6668-0107

Veena Sriram http://orcid.org/0000-0001-7235-253X

\section{REFERENCES}

1 Frenk J, Chen L, Bhutta ZA, et al. Health professionals for a new century: transforming education to strengthen health systems in an interdependent world. Lancet 2010;376:1923-58.

2 Parliament of India. The functioning of the medical Council of India. Rajya Sabha, Parliament of India: Department-Related parliamentary standing Committee on health and family welfare, report no: 92 2016.

3 Government of India. The National medical commission act. Ministry of law and justice, government of India. Report no: 302019.

4 Ravindran TKS, Philip NE. Towards universal health coverage? taking stock of two decades of health reforms in India. India forum, 2020. Available: https://www.theindiaforum.in/article/towardsuniversal-health-coverage [Accessed 10 Jul 2020].

5 Kane S, Calnan M. Erosion of trust in the medical profession in India: time for doctors to act. Int J Health Policy Manag 2017;6:5-8.

6 Marathe S, Hunter BM, Chakravarthi I, et al. The impacts of corporatisation of healthcare on medical practice and professionals in Maharashtra, India. BMJ Glob Health 2020;5:e002026.

7 Cometto G, Buchan J, Dussault G. Developing the health workforce for universal health coverage. Bull World Health Organ 2020;98:109-16.

8 Pandya SK. The medical Council of India: need for a total overhaul. Indian J Med Ethics 2014;11:68-70.

9 NITI Aayog. The National medical Commission bill, 2017. Available: http://niti.gov.in/writereaddata/files/new initiatives/MCl\%20Bill\% 20Final.pdf [Accessed 10 Jul 2020].

10 PRS Legislative Research. The National medical Commission bill, 2017. Available: https://www.prsindia.org/billtrack/national-medicalcommission-bill-2017 [Accessed 10 Jul 2020].

11 Kaul R. Medical Council of India dissolved, replaced with Board of Governors. Hindustan Times [New Delhi], 2018. Available: https:// www.hindustantimes.com/india-news/medical-council-of-indiadissolved-replaced-with-board-of-governors/story-TTrwefRKwcGK q3xCg34COL.html [Accessed 10 Jul 2020]

12 The Times of India [New Delhi]. Process of setting up national medical Commission likely to over in February, 2020. Available: https://timesofindia.indiatimes.com/india/process-of-setting-upnational-medical-commission-likely-to-be-over-in-feb/articleshow/ 73213355.cms [Accessed 10 Jul 2020]

13 Government of India. National Health Policy 2017. Government of India, 2017. Available: https://www.nhp.gov.in/nhpfiles/national health_policy_2017.pdf [Accessed 10 June 2020].

14 NITI Aayog. Health system for new India: building blocks - potential pathways to reform. NITI Aayog, 2019. Available: https://niti.gov. in/sites/default/files/2019-11/NitiAayogBook_compressed.pdf [Accessed 10 Jul 2020].

15 National Health Authority. Ayushman Bharat - Pradhan Mantri Jan Arogya Yojana. Available: https://pmjay.gov.in/about/pmjay [Accessed 10 July 2020].

16 Keshri VR, Gupta SS. Ayushman bharat and road to universal health coverage in India. J Mahatma Gandhi Inst Med Sci 2019;24:65-7.

17 Karan A, Negandhi H, Nair R, et al. Size, composition and distribution of human resource for health in India: new estimates using national sample survey and registry data. BMJ Open 2019;9:e025979.

18 Hindustan Times [New Delhi]. MClapproves increase in PG medical seats by 4800 in 2020-21, 2020. Available: https://www. hindustantimes.com/education/mci-approves-increase-in-pgmedical-seats-by-4800-in-2020-21/story-Qzn5QvrnPb9zvTMn fvL2NM.html [Accessed 10 Jul 2020].

19 Bajpai V. A cure worse than the Malady-National medical Commission act. Economic and Political Weekly 2020;55.

20 Das J, Holla A, Das V, et al. In urban and rural India, a standardized patient study showed low levels of provider training and huge quality gaps. Health Aff 2012;31:2774-84.

21 Chakravarthi, I. and B. M. Hunter (Eds.). Regulation of formal private healthcare providers in Maharashtra: journey of Bombay nursing homes registration act and the clinical establishments act. Pune: SATHI, 2019. Available: http://sathicehat.org/wp-content/uploads/ 2019/09/2.-Witness-Seminar Journey-of-BNHRA PCPNDT.pdf [Accessed 10 July 2020].

22 Nagarajan R. How medical colleges in India became a business, one policy change at a time. The Times of India [New Delhi], 2019. Available: https://timesofindia.indiatimes.com/india/how-medicalcolleges-in-india-became-a-business-one-policy-change-at-a-time/ articleshow/69707594.cms [Accessed $10 \mathrm{Jul}$ 2020].

23 Government of India. The Indian medical Commission (Amendment) ordinance. Ministry of health and family welfare, government of India; 2018. ordinance 8 of 20182018. 